\title{
Supply chain finance, financial development and profitability of real estate firms in Vietnam
}

\author{
Toan Ngoc Bui ${ }^{*}$
}

${ }^{a}$ Faculty of Finance and Banking, Industrial University of Ho Chi Minh City (IUH), Vietnam

\begin{tabular}{l}
\hline C H R O N I C L E \\
\hline Article history: \\
Received July 28, 2019 \\
Received in revised format \\
August 29, 2019 \\
Accepted September 62019 \\
Available online \\
September 62019 \\
\hline Keywords: \\
Supply chain finance \\
Financial development \\
Profitability \\
Real estate \\
Vietnam \\
\hline
\end{tabular}

\section{A B S T R A C T}

\begin{abstract}
This paper investigates the impact of supply chain finance (SCF) and financial development on profitability of real estate firms in Vietnam over the 2013 - 2017 period. This is the first empirical research examining the impact of financial development on firm profitability. By employing GMM (generalized method of moment), this paper reveals the important role of supply chain finance (SCF) and financial development in profitability of real estate firms. Specifically, firm profitability $(\mathrm{P})$ is influenced negatively by cash conversion cycle (CCC) and positively by financial development (FD). In addition, profitability is negatively correlated with control variable of financial leverage (LEV) and positively associated with control variable of firm size (SIZE). The findings reveal the role of supply chain finance and financial development in firm profitability which policymakers as well as managers at real estate firms can apply suitable methods in order to improve firms' profits.
\end{abstract}

(C) 2020 by the authors; license Growing Science, Canada.

\section{Introduction}

After the global financial crisis, Vietnam economy made an impressive recovery which has positive significant effects on real estate industry. That brings many opportunities for Vietnam's real estate companies to extend its market. However, this extension also brings them big challenges, especially to their limited management skills, so it is compulsory to adjust their business operation and management skills, especially to improve capital approach ability in order to expand their financial capacities as well as markets. In specific, participating and completing supply chain finance (SCF) is the most concerned issue of real estate firms because these activities together with improving capital approach ability play vital roles in the process of market expansion. SCF brings companies more opportunities to access to capital (Marak \& Pillai, 2019). The fact that SCF works ineffectively and capital approach ability is limited will increase risks or interruption in the operation of supply chain (Raddatz, 2010). Furthermore, SCF also brings companies more profits and efficiency (Lekkakos \& Serrano, 2016). Especially, after an economic crisis, credit sources and trade credits from suppliers become constrained so it is even imperative for Vietnam economy which has just experienced that difficulty period from 2011 to 2012 to complete SCF and raise capital approach ability. Moreover, supply chain finance allows its participants to reach their targets in cutting capital cost, optimizing working capital as well as boosting profits (Raghavan \& Mishra, 2011). Despite its importance, supply chain finance has been a relatively new topic to most empirical studies (Caniato et al., 2016). Meanwhile, most of empirical research on SCF have not used data from financial statements in a wide range of companies, but only surveys or

* Corresponding author

E-mail address: buingoctoan@iuh.edu.vn (T.N. Bui)

(C) 2020 by the authors; licensee Growing Science. doi: $10.5267 /$ j.uscm.2019.9.001 
in-depth interviews (Dong et al., 2007). The participation in SCF is not only to optimize companies' working capital but also to access to medium-term and long-term bank loans. Consequently, national financial development really helps companies improve their capital approach abilities as well as profits. Especially for Vietnam, a developing country with a new stock market, credit source is a key factor in supplying capital for real estate firms. The economic recovery and financial development have been quite optimistic in recent years (Fig. 1). That contributes a lot in raising profits of real estate companies.

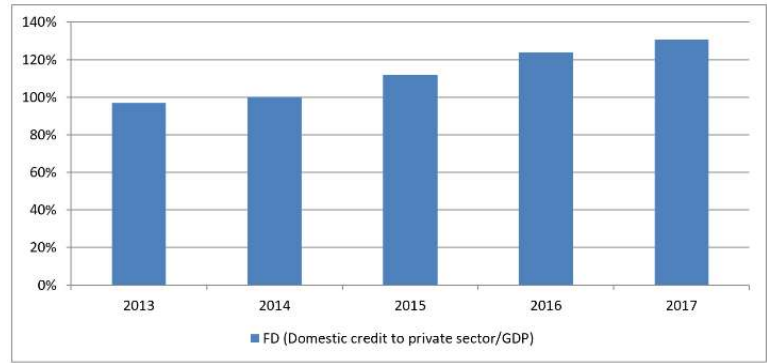

Fig. 1. Financial development in Vietnam (Source: World Bank)

To financial development, most empirical studies are mainly focused on analyzing its role in the economy. Meanwhile, its specific impact on firm profits has not been paid attention yet. Thus, this paper is conducted in the objective of giving empirical evidence on the impact of SCF and financial development on profitability of real estate firms. Its results are expected to help policymakers as well as managers at real estate firms acknowledge the importance of supply chain finance and financial development to firm profitability.

\section{Literature review and research hypothesis}

\subsection{Supply chain finance and firm profitability}

Supply chain finance (SCF) has been brought in empirical research since the beginning of $21^{\text {St }}$ century (Pfohl \& Gomm, 2009). Accordingly, SCF is essential in providing both buyers and sellers with shortterm credit. SCF works effectively when being operated on the technological basis by automating all transactions and tracking the entire payment process. SCF helps reduce bankruptcy and uncertainty in the supply chain (Klapper, 2006) in order to stabilize the supply chain. SCF also contributes towards optimizing the company financial flows (Pfohl \& Gomm, 2009). In other words, SCF aims to reduce capital cost, increase cash flow rate and increase financial relation among the supply chain participants (Wuttke et al., 2013). Specially, after some economic predicaments, the management aims to the improvement of supply chain finance (Polak et al., 2012). Companies expect to expand trade credit from their suppliers to optimize the working capital. This means that SCF allows the optimization of its working capital and financial liquidity (Liebl et al., 2016). As a result, SCF brings its participants more profits. About the measurement of SCF, empirical studies usually use indicator of cash conversion cycle (CCC) (Zhang et al., 2019). CCC is an effective measure in working capital management which can perfectly represent SCF and concurrently act as a key for the management of the entire supply chain (Farris \& Hutchison, 2002). Accordingly, CCC covers the period starting from the cash outlay to cash recovery (Fig. 2).

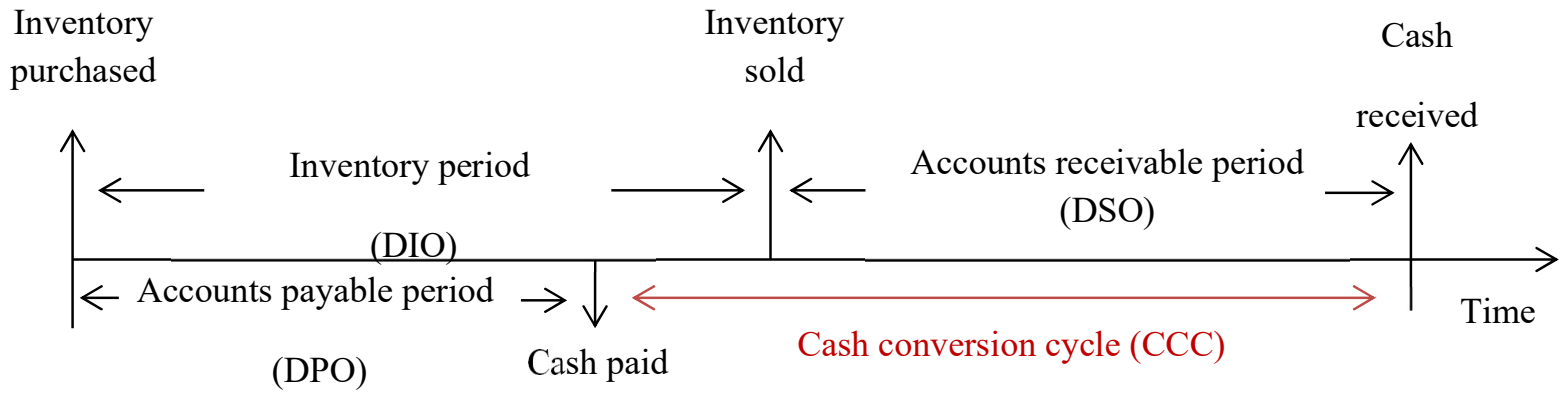

Fig. 2. Individual firm-oriented cash conversion cycle (CCC) (Source: Zhang et al. (2019)) 
To shorten CCC means that the time for cash recovery becomes shorter and companies can increase their working capital (constraining capital tie-up) for costs and investment, and then improve firm profitability (Gul et al., 2013). In general, SCF plays a vital role in improving profitability of the supply chain participants. In other words, if CCC is low, the cash recovery period will be shortened and the profits will increase. Therefore, the research hypothesis is suggested as follows:

$\mathrm{H}_{1}$ : Cash conversion cycle (CCC) has a negative impact on firm profitability $(\mathrm{P})$.

\subsection{Financial development and firm profitability.}

According to Zaman et al. (2012), financial development can be seen as development on the general scale of finance and efficiency of financial individual participants. When finance grows effectively, it will be more advantageous for companies to access to capital, especially medium-term and long-term one. Accordingly, they can increase their investment and improve their profits. Thus, Fowowe (2017) asserted that companies (across 30 African countries) which are not credit constrained grow faster than those which are credit constrained. Financial development also raises the value of household assets. That makes them feel wealthier, then increase their expenditure, their investment as well as their housing needs. Consequently, customers of real estate firms can reach higher consumption ability, so that brings these firms more profits. The role of financial development in the economy has been examined in many empirical research (Adeniyi et al., 2015). However, specific effects of financial development on firm profitability has rarely been researched despite their significant existence. Financial development is measured by indicator of domestic credit to private sector (\% of GDP) (Lim, 2018; Pradhan et al., 2018; Eren et al., 2019). Generally, the effective financial development can improve firm profitability, so the following hypothesis is suggested:

$\mathrm{H}_{2}$ : Financial development (FD) has a positive impact on firm profitability (P).

\section{Data and Methodology}

\subsection{Data Collection}

The paper uses data from World Bank and financial statements of 35 real estate firms listed on Ho Chi Minh Stock Exchange which is the first centralized and biggest exchange in Vietnam. Its data covers the 2013-2017 period. Since 2013, Vietnam economy has firmly recovered after the difficult time, so this period is chosen to assure that the findings are stable and reflect the actual situations accurately.

\subsection{Methodology}

The author employs regression methods using panel data which consists of Pooled regression (Pooled OLS), Fixed effects model (FEM) and Random effects model (REM). In order to select the most appropriate model, F-test is used to giving a choice between Pooled OLS and FEM; meanwhile, Hausman test is used to choose between FEM and REM.

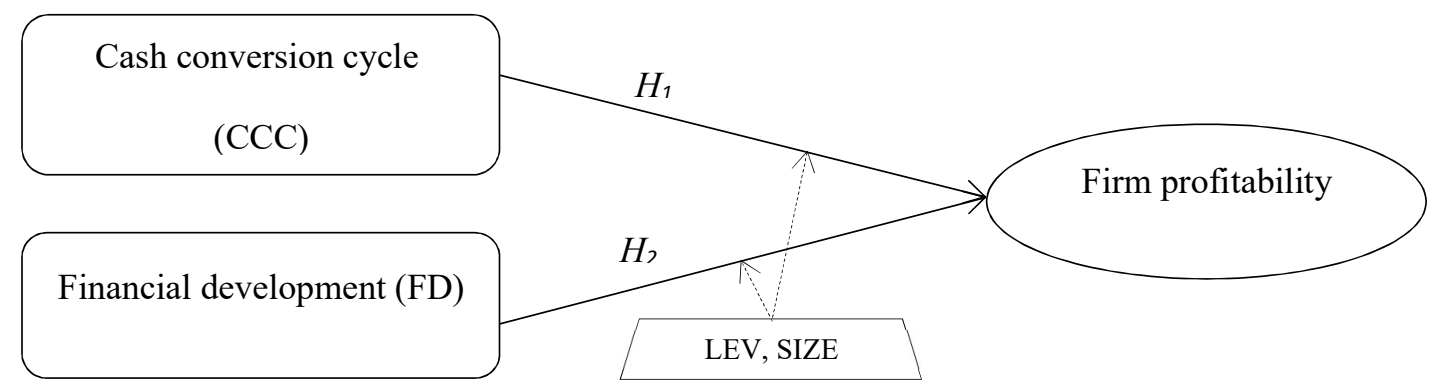

Source: Compiled by the authors based on theory and prior literature.

Fig. 3. Impact of cash conversion cycle and financial development on profitability

Based on the most appropriate model, the author then conducts testing on multicollinearity, heteroscedasticity and autocorrelation among errors. After that, Generalized Method of Moment (GMM) is applied to resolve potential endogenous problems. According to Driffill et al. (1998), GMM 
is better than other regression methods using panel data in testing motion of financial variables. According to earlier findings, profitability is influenced by cash conversion cycle (CCC) which is an indicator of supply chain finance (SCF). Further, variable of financial development (FD) which is anticipated to affect firm profitability is brought in, too. Additionally, firm profitability may be also correlated with other firm-specific control variables, e.g. financial leverage (LEV), firm size (SIZE) (Gul et al., 2013). Consequently, the research model is estimated using the following equation:

In which:

$$
\mathrm{P}_{\mathrm{it}}=\beta_{0}+\beta_{1} \mathrm{CCC}_{\mathrm{it}}+\beta_{2} \mathrm{FD}_{\mathrm{it}}+\beta_{3} \mathrm{CAP}_{\mathrm{it}}+\beta_{4} \mathrm{SIZE}_{\mathrm{it}}+\varepsilon_{\mathrm{it}}
$$

Dependent variable: Firm profitability $(\mathrm{P})$.

Independent variables: Cash conversion cycle (CCC), financial development (FD).

Control variables: Financial leverage (LEV), firm size (SIZE).

Table 1

Summary of variables

\begin{tabular}{|c|c|c|}
\hline Variables & Code & Measurements \\
\hline \multirow{3}{*}{ Firm profitability } & & Dependent variable \\
\hline & $\mathrm{P}$ & Net profit / Total assets \\
\hline & & Independent variables \\
\hline \multirow[t]{4}{*}{ Cash conversion cycle } & $\mathrm{CCC}$ & Days receivable + Days inventories - Days payable \\
\hline & & Day Receivable $=($ trade receivable $/$ sales $) * 365$ \\
\hline & & Days Inventory $=($ total inventories $/$ cost of goods sold $) * 365$ \\
\hline & & Days Payable $=($ trades payable $/$ cost of goods sold $) * 365$ \\
\hline Financial development & FD & $\begin{array}{l}\text { Domestic credit to private sector / GDP } \\
\text { Control variables }\end{array}$ \\
\hline Financial leverage & LEV & Total debt / Total assets \\
\hline Firm size & SIZE & Logarithm of total assets \\
\hline
\end{tabular}

Source: Compiled by the authors based on theory and prior literature.

\section{Empirical Results}

Variable correlations are shown in Table 2:

Table 2

Variable correlations

\begin{tabular}{cccccc}
\hline & P & CCC & FD & LEV & SIZE \\
\hline P & 1.0000 & & & & \\
FD & -0.3204 & 1.0000 & & & \\
LEV & 0.4919 & -0.2052 & 1.0000 & 1.0000 & 1.0000 \\
SIZE & -0.1879 & -0.0161 & -0.0109 & 0.1080 & 0.1114 \\
\hline
\end{tabular}

Source: Author's computed

Table 2 indicates that variables of cash conversion cycle (CCC) and financial leverage (LEV) are negatively correlated with firm profitability (P). Meanwhile, variables of financial development (FD) and firm size (SIZE) have a positive association with firm profitability (P). Table 3 reveals no serious problems of multicollinearity and autocorrelation. However, heteroscedasticity has significance at the $1 \%$ level. The paper uses Pooled regression (Pooled OLS), Fixed effects model (FEM) and Random effects model (REM). Results of Hausman test show REM is more appropriate. However, heteroscedasticity really exists in this model. Therefore, Generalized Method of Moment (GMM) is chosen to control this problem in order to assure stable and effective estimated results.

Table 3

Results of tests on multicollinearity, heteroscedasticity and autocorrelation

\begin{tabular}{|c|c|c|c|c|}
\hline \multicolumn{3}{|c|}{ Multicollinearity test } & \multirow{2}{*}{ Heteroscedasticity test } & \multirow{2}{*}{ Autocorrelation test } \\
\hline Variable & VIF & $1 / \mathrm{VIF}$ & & \\
\hline $\mathrm{CCC}$ & 1.19 & 0.8388 & \multirow{5}{*}{ Prob $>$ chibar $2=0.0000^{* * *}$} & \multirow{5}{*}{ Prob $>F=0.2317$} \\
\hline SIZE & 1.17 & 0.8546 & & \\
\hline FD & 1.05 & 0.9560 & & \\
\hline LEV & 1.01 & 0.9874 & & \\
\hline \multicolumn{3}{|c|}{ Mean VIF $=1.11$} & & \\
\hline
\end{tabular}


Table 4

Regression results

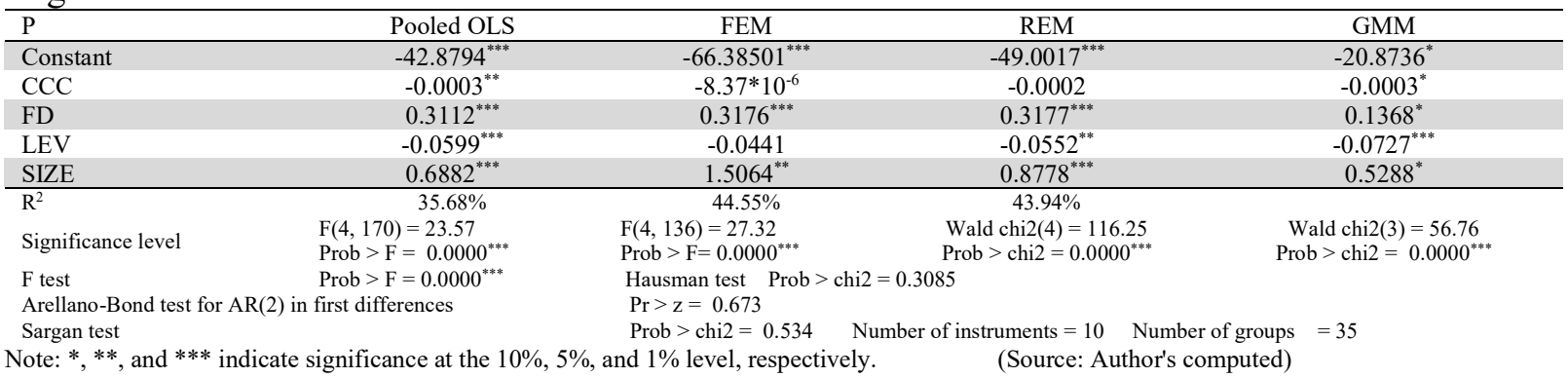

Also, according to Doytch and Uctum (2011), GMM can resolve potential endogenous problems. As can be seen in Table 4, the results of GMM are appropriate and utilizable. Accordingly, independent variable which is cash conversion cycle $(\mathrm{CCC})$ exerts negative effects $(-0.0003)$ on firm profitability $(\mathrm{P})$ at the $10 \%$ level of significance. Independent variable of financial development (FD) has a positive influence $(0.1368)$ on firm profitability $(\mathrm{P})$ at the $10 \%$ level of significance. In addition, there exists a negative relationship (-0.0727) between financial leverage (LEV) and firm profitability $(\mathrm{P})$ at the $1 \%$ significance level, and a positive correlation (0.5288) between firm size (SIZE) and firm profitability (P) at the 10\% level of significance. Accordingly, the results reveal that supply chain finance and financial development play vital roles in improving profitability of real estate firms in Vietnam.

About supply chain finance: Cash conversion cycle (CCC) negatively contributes to firm profitability $(\mathrm{P})$, so the hypothesis $\mathrm{H}_{1}$ is accepted. This means that supply chain finance allows its participants to shorten cash conversion cycle, increase their working capital as well as maintain their funds in order to sufficiently supply to next operation cycle, reduce external sources, costs, risks and ultimately improve profits. This result supports what was reported by Gul et al. (2013), Zhang et al. (2019).

About financial development: Financial development (FD) exerts positive effects on firm profitability (P), so the hypothesis $\mathrm{H}_{2}$ is accepted. This has not been found in earlier studies. Accordingly, it can be concluded that effective financial development helps firms access capital easily, especially mediumterm and long-term credits. Also, consumption on real estate will raise. Hence, it contributes to the profit improvement.

\section{Conclusions}

The results reveal that supply chain finance (SCF) and financial development are the key factors in improving profitability of real estate firms in Vietnam. Specifically, firm profitability $(\mathrm{P})$ is negatively influenced by cash conversion cycle (CCC). Furthermore, it was positively affected by financial development (FD). This is a new finding of this study. Accordingly, this indicates that optimizing working capital by shortening cash conversion cycle and improving capital approach ability (mediumterm and long-term credits specially) will contribute to real estate firms in gaining more profits. Besides, financial leverage (LEV) has a negative impact and firm size (SIZE) has a positive impact on firm profitability $(\mathrm{P})$. Based on these findings, policymakers and managers in real estate firms can recognize the effects of supply chain finance and financial development on firm profitability. Therefore, some implications of these results are suggested to improve profitability of real estate firms as follows: (1) To policymakers, it is necessary to establish suitable policies in the aim of effective financial development, so real estate firms can have more opportunities to access the capital, especially mediumterm and long-term credits; (2) To managers in real estate firms, it is essential to boost the participation and completion of supply chain finance. Concurrently, firm operational efficiency also needs improving to easily access to external sources, e.g. credits, capital raised though stock markets. This paper succeeds in giving empirical evidence regarding effects of supply chain finance and financial development on profitability of real estate firms. Nevertheless, the paper has its own limitations when excluding other control variables which may exert certain association on firm profitability (e.g. 
macroeconomic factors) and firms in different fields so that comparison can be made. That will be an interesting research for future studies.

\section{References}

Adeniyi, O., Oyinlola, A., Omisakin, O., \& Egwaikhide, F. O. (2015). Financial development and economic growth in Nigeria: Evidence from threshold modelling. Economic Analysis and Policy, 47, 11-21.

Caniato, F., Gelsomino, L. M., Perego, A., \& Ronchi, S. (2016). Does finance solve the supply chain financing problem? Supply Chain Management, 21(5), 534-549.

Dong, Y., Xu, K., \& Dresner, M. (2007). Environmental determinants of VMI adoption: an exploratory analysis. Transportation Research Part E: Logistics and Transportation Review, 43(4), 355-369.

Doytch, N., \& Uctum, M. (2011). Does the worldwide shift of FDI from manufacturing to services accelerate economic growth? A GMM estimation study. Journal of International Money and Finance, 30(3), 410-427.

Driffill, J., Psaradakis, Z., \& Sola, M. (1998). Testing the expectations hypothesis of the term structure using instrumental variables. International Journal of Finance and Economics, 3(4), 321-325.

Eren, B. M., Taspinar, N., \& Gokmenoglu, K. K. (2019). The impact of financial development and economic growth on renewable energy consumption: Empirical analysis of India. Science of The Total Environment, 663, 189-197.

Farris, M. T, \& Hutchison, P. D. (2002). Cash-to-Cash: the new supply chain management metric. International Journal of Physical Distribution \& Logistics Management, 32(4), 288-298.

Fowowe, B. (2017). Access to finance and firm performance: Evidence from African countries. Review of Development Finance, 7(1), 6-17.

Gul, S., Khan, M. B., Rehman, S. U., Khan, M. T., Khan, M., \& Khan, W. (2013). Working Capital Management and Performance of SME Sector. European Journal of Business and Management, 5(1), 60-68.

Klapper, L. F. (2006). The role of factoring for financing small and medium enterprises. Journal of Banking \& Finance, 30(11), 3111-3130.

Lekkakos, S. D., \& Serrano, A. (2016). Supply chain finance for small and medium sized enterprises: the case of reverse factoring. International Journal of Physical Distribution \& Logistics Management, 46(4), 367392.

Liebl, J., Hartmann, E., \& Feisel, E. (2016). Reverse factoring in the supply chain: objectives, antecedents and implementation barriers. International Journal of Physical Distribution \& Logistics Management, 46(4), 393-413.

Lim, T. (2018). Growth, financial development, and housing booms. Economic Modelling, 69, 91-102.

Marak, Z. R., \& Pillai, D. (2019). Factors, Outcome, and the Solutions of Supply Chain Finance: Review and the Future Directions. Journal of Risk and Financial Management, 12(3), 1-23.

Pfohl, H. C., \& Gomm, M. (2009). Supply chain finance: optimizing financial flows in supply chains. Logistics Research, 1(3), 149-161.

Polak, P., Sirpal, R., \& Hamdan, M. (2012). Post-crisis emerging role of the treasurer. European Journal of Scientific Research, 86(3), 319-339.

Pradhan, R., Arvin, M., Hall, J., \& Bahmani, S. (2014). Causal nexus between economic growth, banking sector development, stock market development, and other macroeconomic variables: The case of ASEAN countries. Review of Financial Economics, 23(4), 155-173.

Raddatz, C. (2010). Credit chains and sectoral comovement: Does the use of trade credit amplify sectoral shocks?. The Review of Economics and Statistics, 92(4), 985-1003.

Raghavan, N. S., \& Mishra, V. K. (2011). Short-term financing in a cash-constrained supply chain. International Journal of Production Economics, 134(2), 407-412.

Zaman, K., Izhar, Z., Khan, M. M., \& Ahmad, M. (2012). The relationship between financial indicators and human development in Pakistan. Economic Modelling, 29(5), 1515-1523.

Zhang, T., Zhang, C. Y., \& Pei, Q. (2019). Misconception of Providing Supply Chain Finance: Its Stabilising Role. International Journal of Production Economics, 213, 175-184.

Wuttke, D. A., Blome, C., Foerstl, K., \& Henke, M. (2013). Managing the innovation adoption of supply chain finance - empirical evidence from six European case studies. Journal of Business Logistics, 34(2), 148-166.

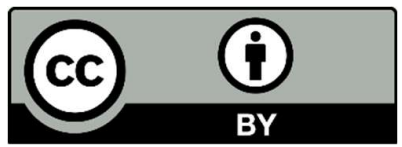

(C) 2020 by the authors; licensee Growing Science, Canada. This is an open access article distributed under the terms and conditions of the Creative Commons Attribution (CC-BY) license (http://creativecommons.org/licenses/by/4.0/). 